\title{
Toxicity from Nanomaterials: What to be Concerned
}

\author{
Viroj Wiwanitkit* \\ Senior Expert, Surin Rajabhat University, Thailand
}

Received: December 25, 2015; Accepted: December 27, 2015; Published: December 29, 2015

*Corresponding author: Viroj Wiwanitkit, Surin Rajabhat University, Thailand, E-mail: wviroj@yahoo.com

\section{Editorial}

Nanomaterial becomes widely used at present. It is no doubt that there is a lot of usefulness of nanomaterial. On the other side of the coin, the possible adverse effect of nanomaterial can be expected. The toxicity due to nanomaterial is an interesting topic in nanoscience. First, it should mention that the toxicity of nanomaterial is confirmed. Toxicities on hematological and genitourinary system in experimental models are reported [1-3]. Nevertheless, the actual situation in real life should be discussed. It should be noted that there are some existed natural nanomaterials. Those materials can be either organic or inorganic. The toxicities due to uptake of those natural materials into human body are widely discussed. The interesting situation is the GMO nanomaterials [4]. Indeed, several genes are in nanoscale and human beings generally intake genes in their foods. For sure, there is no problem for those cases. This should be the same for the GMO nanomaterials in food. However, for case of inorganic substances such as nanometals, the accumulation will result in toxicity. For the synthesized nanomaterials, the important requirement before allowance for general usage is the proof for toxicity in vitro and in vivo. In the era of "nano", we should not fear but control the use of nanomaterials. Cytotoxicity genotoxicity as well as possible toxicity due to epigenetic mechanisms should be focused in future studied [5].

\section{References}

1. Wiwanitkit V, Sereemaspun A, Rojanathanes R. Effect of gold nanoparticles on spermatozoa: the first world report. FertilSteril. 2009; 91(1): e7-8.

2. Wiwanitkit V, Sereemaspun A, Rojanathanes R. Effect of gold nanoparticle on the microscopic morphology of white blood cell. Cytopathology. 2009; 20(2): 109-10.

3. Wiwanitkit V, Sereemaspun A, Rojanathanes R. Gold nanoparticles and a microscopic view of platelets: a preliminary observation. Cardiovasc J Afr. 2009; 20(2): 141-2.

4. Yau NJ. New technology for food systems and security. Asia Pac J ClinNutr. 2009; 18(4): 546-8.

5. Shyamasundar S, Ng CT, Yung LY, Dheen ST, Bay BH. Epigenetic mechanisms in nanomaterial-induced toxicity. Epigenomics. 2015; 7(3): 395-411. 